Eduvest - Journal of Universal Studies

Volume 2 Number 2, February 2022

p- ISSN 2775-3735 e-ISSN 2775-3727

\title{
PERCEPTION ANALYSIS OF HEALTH WORKERS' STRESS DURING THE COVID-19 PANDEMIC
}

\author{
Heriziana , Santi Rosalina
}

Bina Husada High School of Health Sciences, Indonesia

Email: zhie.hz27@gmail.com, santirosalina22177@gmail.com

\begin{tabular}{|c|c|}
\hline ARTICLE INFO & ABSTRACT \\
\hline $\begin{array}{l}\text { Received: } \\
\text { January, 26 } \\
2022 \\
\text { Revised: } \\
\text { February, 17th } \\
2022 \\
\text { Approved: } \\
\text { February, } 18^{\text {th }} \\
2022\end{array}$ & $\begin{array}{l}\text { The COVID-19 pandemic has had a profound effect on all } \\
\text { aspects of society, including mental health and physical } \\
\text { health. WHO and public health authorities around the } \\
\text { world are acting to control the COVID-19 outbreak. } \\
\text { However, this time of crisis creates stress throughout the } \\
\text { population. Fear and anxiety about this new disease, plus } \\
\text { other factors can influence job stress. The type of research } \\
\text { used is correlation research. This research was conducted at } \\
\text { X Hospital in South Sumatra 2021. The population of this } \\
\text { study was all health workers at Hospital X in South Sumatra } \\
2021 \text {, totaling } 382 \text { people based on staffing data for } \\
\text { Hospital X in South Sumatra as of March 2021. The sample } \\
\text { of this study that will be examined using the slovin formula, } \\
\text { which amounts to } 80 \text { health workers at the hospital. Pain X } \\
\text { in South Sumatra. Based on the results and discussion, it } \\
\text { can be concluded that: The company's regulation (X1) has a } \\
\text { significance value of } 0.743>0.05 \text {, which means that the } \\
\text { company's regulation (X1) has no effect on stress symptoms } \\
\text { (Y). Anxiety (X2) has a significance value of } 0.461>0.05 \text {, } \\
\text { which means that worry (X2) has no effect on symptoms of } \\
\text { stress (Y). Workload (X3) a significance value of } 0.007 \\
<0.05, \text { it means that there is an effect of workload (X3) on } \\
\text { stress symptoms. Working conditions (X4), a significance } \\
\text { value of } 0.023<0.05 \text {, it means that there is an effect of } \\
\text { working conditions (X4) on symptoms of stress. }\end{array}$ \\
\hline KEYWORI & $\begin{array}{l}\text { Health Workers, Stress, Mental Health, Pandemic Covid- } \\
19\end{array}$ \\
\hline
\end{tabular}

Heriziana, Santi Rosalina.(2022). Perception Analysis of Health

Workers' Stress During the Covid-19 Pandemic. Journal Eduvest. Vol

How to cite: $\quad 2(2): 317-323$

E-ISSN: $\quad 2775-3727$

Published by: $\quad$ https://greenpublisher.id/ 


\section{INTRODUCTION}

Currently, all parts of the world are facing the Covid-19 pandemic. Until the beginning of June, 6.28 million people from 188 countries in the world were infected with the Covid-19 virus, while in Indonesia alone, 26,940 people were infected with the Covid-19 virus (Covid et al., 2021). Covid-19 is a tremendous challenge to the health of workers. Workers in many occupations face a high risk of infection especially in jobs that involve direct contact with the public and physical proximity to others. The level of concern of workers increases with the number of infected people, as a result, companies not only play a role in preventing the transmission of the virus but also have to deal with the psychosocial and psychological consequences of the current Covid-19 outbreak (Burdorf, Porru, \& Rugulies, 2020)

Increased fear and anxiety of workers due to the uncertainty of this disease coupled with measures to prevent the spread of disturbing viruses such as lockdowns, quarantines, use of personal protective equipment, and so on can cause significant psychological and psychological disorders such as stress disorders (Kumar, n.d.). The COVID-19 pandemic in Indonesia has resulted in a very heavy burden on the health care system in the country, including health workers. The most visible risk is the safety aspect of health workers, especially those on the front lines, who are very vulnerable to being exposed to COVID-19 and are at risk of life threatening.

It has been recorded that more than 100 doctors and hundreds of other medical personnel have died from being infected with COVID-19 while carrying out health service duties. Apart from the aspect of safety and protection from infection, another risk that has the potential to affect the quality of life and productivity of our medical services is the mental health aspect, including the risk of burnout syndrome or mental fatigue. Health workers are potentially exposed to very high levels of stress, but there are no rules or policies that can protect them from a mental health perspective (Meidina et al., 2020)

Research conducted by a research team from the Master of Occupational Medicine Study Program, Faculty of Medicine, University of Indonesia (MKK FKUI) shows the fact that as many as $83 \%$ of health workers in Indonesia have experienced moderate and severe burnout syndrome, which is psychologically at risk of disrupting quality of life and work productivity in services. health.

According to the Head of the Research Team, Dr. dr. Dewi Soemarko, MS, $\mathrm{SpOK}$, this study also found the fact that General Practitioners in Indonesia who carry out medical service duties at the forefront during the COVID-19 Pandemic have a 2 times greater risk of experiencing burnout syndrome.

"The high risk of suffering from burnout syndrome due to exposure to unusually severe stress in health facilities during this pandemic can have long-term effects on the quality of medical services because these health workers can feel depressed, extreme fatigue and even feel less competent in carrying out their duties, and this is certainly have an unfavorable impact on our efforts to combat COVID-19," (Tresnaherdiarti, 2021)

The COVID-19 pandemic has had a profound effect on all aspects of society, including mental health and physical health. WHO and public health authorities around the world are acting to control the COVID-19 outbreak. However, this time of crisis creates stress throughout the population. Fear and anxiety about this new disease, plus other factors can influence job stress (Organization, 2021)". 


\section{RESEARCH METHOD}

The type of research used is correlation research. This research was conducted at X Hospital in South Sumatra 2021. The population of this study was all health workers at Hospital X in South Sumatra 2021, totaling 382 people based on staffing data for Hospital X in South Sumatra as of March 2021. The sample of this study that will be examined using the slovin formula, which amounts to 80 health workers at the hospital. Pain X in South Sumatra. The steps of data processing in this study are as follows:

1. The weighting of each variable formula:

Calculation of the weight value of each variable is carried out using the following

Weight value $=($ Amount of Strongly Agree x 5) $+($ Number of Agree x 4) + (Number of Disagree x 3$)+($ Number of Disagree x 2$)+($ Number of Disagree x 1)

2. Multiple linear regression test

Multiple linear regression test was used to find out how much influence the variables of Company Regulation (X1), Concerns (X2), Workload (X3), Working Conditions (X4) had with the dependent variable stress symptoms (Y).

\section{RESULT AND DISCUSSION}

\section{A. Univariate Results}

Univariate analysis was carried out to obtain an overview of the frequency distribution of respondents based on the stress symptom variables collected in tables and texts as below:

Table 1 Distribution of Respondents Frequency Based on Symptoms of Stress at X Hospital in South Sumatra 2021

$\begin{array}{llll}\text { No } & \text { Stress Symptoms } & \text { Frekuency } & \text { Percentage (\%) } \\ 1 & \text { There are Symptoms of Stress } & 43 & 53.8 \\ 2 & \text { No Stress Symptoms } & 37 & 46.3 \\ \text { Total } & & 80 & 80\end{array}$

Based on Table 1, the number of respondents who experienced stress symptoms was 43 respondents (53.8\%) from 80 respondents, more than respondents who did not experience stress symptoms, namely 37 respondents $(46.3 \%)$.

\section{B. Multiple Linear Regression Test on Health Workers at Hospital X in South Sumatra}

The results of the multiple linear regression test data processing for health workers can be seen as follows.

1. Partial Test (t Test) on Each Variable

.Table 2. Partial Test Results (t Test) on Each Variable

\section{Coefficients}




\begin{tabular}{lllll|l|l} 
& \multicolumn{2}{l}{$\begin{array}{l}\text { Unstandardized } \\
\text { Coefficients }\end{array}$} & \multicolumn{2}{l}{$\begin{array}{l}\text { Standardized } \\
\text { Coefficients }\end{array}$} & & \\
Model & B & Std. Error & Beta & t & Sig. \\
\hline 1(Constant) & 11.332 & 6.500 & & 1.743 & .085 \\
\hline X1 (Company Regulation) & -.050 & .152 & -.042 & -.330 & .743 \\
\hline X2 (Worries) & .289 & .390 & .083 & .742 & .461 \\
\hline X3 (Workload) & .352 & .128 & .299 & 2.759 & .007 \\
\hline X4 (Working Condition) & .726 & .313 & .288 & 2.322 & .023 \\
\hline
\end{tabular}

1. Dependent Variable: Gejala Stres

Based on table 2, the results of the partial test (t test) on each variable. The basis for making decisions based on the significance value is as follows:

1. Company regulation (X1) significance value $0.743>0.05$ which means company regulation (X1) has no effect on stress symptoms (Y)

2. Concern (X2) significance value $0.461>0.05$, which means worry $(\mathrm{X} 2)$ has no effect on stress symptoms (Y)

3. Workload (X3) a significance value of $0.007<0.05$, which means that there is an effect of workload (X3) on stress symptoms.

4. Working conditions (X4), a significance value of $0.023<0.05$, it means that there is an effect of working conditions (X4) on stress symptoms.

2. Simultaneous Test (Test f) on Each Variable

Table 3. Simultaneous F Test Results (Multiple Linear Regression)

ANOVA $^{\mathrm{a}}$

\begin{tabular}{llllllll} 
Model & & \multicolumn{2}{l}{ Sum of Squares } & df & Mean Square & F & Sig. \\
\hline 1 & Regression & 4302.733 & 4 & 1075.683 & 5.027 & $.001^{\text {b }}$ \\
\cline { 2 - 7 } & Residual & 16049.067 & 75 & 213.988 & & \\
\cline { 2 - 7 } & Total & 20351.800 & 79 & & & \\
\hline
\end{tabular}

a. Dependent Variable: Y(Gejala Stres)

b. Predictors: (Constant), X4 (Working Conditions), X2 (Worries), X3 (Workload), X1

(Company Regulations)

Based on table 4.1 Simultaneous multiple linear regression $\mathrm{f}$ test results. The basis for decision making based on the significance value is company regulation (X1), worries (X2), workload (X3), and working conditions (X4) simultaneously affect stress symptoms $(\mathrm{Y})$ seen of the significance value is $0.001<0.05$.

Model Summary ${ }^{\mathrm{b}}$

Table 3 Results of the Coefficient of Determination (R2)

\begin{tabular}{llllll} 
Model & R & R Square & $\begin{array}{l}\text { Adjusted R } \\
\text { Square }\end{array}$ & \multicolumn{2}{l}{$\begin{array}{l}\text { Std. Error of the } \\
\text { Estimate }\end{array}$} \\
\hline 1 & $.460^{\mathrm{a}}$ & .211 & .169 & 14.628 & Durbin-Watson \\
\hline a. Predictors: (Constant), TotalKK, TotalK, TotalBK, TOTALRP
\end{tabular}




\section{b. Dependent Variable: TOTALGS}

Based on table 4.4 the results of the coefficient of determination, namely the magnitude of the effect given by variable $\mathrm{X}$ partially and simultaneously on variable $\mathrm{Y}$, is $21.1 \%$.

\section{Discussion}

\section{Stress Analysis of Health Workers at Hospital X in South Sumatra}

Based on the processing results, it was found that the variables of workload and working conditions had an influence on stress symptoms in health workers.(OgińskaBulik, Gurowiec, Michalska, \& Kędra, 2021) This can be caused by differences in duties and responsibilities as health workers and for different working conditions. Where with the current pandemic conditions there must be anxiety felt by health workers at work so that it adds to the burden and pressure at work.(Søvold et al., 2021) In addition, working conditions require health workers to continue to work even in pandemic conditions because they are the frontline who must be ready to serve patients with any condition.

Based on the theory (Gawron, 2008) Workload is defined as the effort expended by the operator to achieve a certain level of performance or can also be defined as a response (emotional, cognitive, and physical) to the demands of work. A high workload can be a challenge for workers and motivate them to try harder to meet the demands of the job. On the other hand, a high workload can also lead to negative emotional reactions and physical exhaustion associated with overwork. Thus, workers' cognitive and emotional resources can be depleted by stressors, resulting in impaired performance (Elfering et al., 2018).

According to the theory (Iridiastadi 2014) excessive workload can also have a negative impact on work quality and performance.(Mélan \& Cascino, 2022) That the workload is physiologically excessive will have an impact on health and work productivity. In the context of ergonomics, the goal to be achieved is to ensure that the work system is designed in such a way that the best productivity and quality of work can be obtained, which can be achieved if the load is within the limits of physical capabilities. Workload evaluation is an important point in research and development of the relationship between humans and machines, seeking a better level of comfort, satisfaction, efficiency and safety in the workplace, as well as the targets for achieving ergonomics implementation.

Based on the theory (AGASTIA, 2014) Working conditions are conditions that are around work that have an impact on workers in carrying out their duties. Workers will feel satisfaction at work if it is supported by good working conditions or environment, so that the company's performance and output can increase.(Badrianto \& Ekhsan, 2020) On the other hand, unsupportive working conditions can cause discomfort at work and contribute to work stress.(Cramer \& Hunter, 2019)

This study is in line with the study (Luceño-Moreno et al., n.d.) that analyzed cross-sectional data on 1422 health workers. A total of $56.6 \%$ of health workers showed symptoms of post-traumatic stress disorder, $58.6 \%$ of anxiety disorders, $46 \%$ of depressive disorders, and $41.1 \%$ felt emotionally drained.(d'Ettorre et al., 2021) The profile of the health worker with greater symptoms of post-traumatic stress is one who works in the Autonomous Community of Madrid, in a hospital, is a woman, is worried that the person living with her may be infected, and thinks that she/he is very likely to be 


\section{Heriziana, Santi Rosalina}

infected. The risk variables for anxiety and depression were people who were female, worked 12 or 24 hour shifts, and were worried that family members could be infected. High scores on emotional exhaustion and depersonalization are mental health risk factors, with resilience and personal fulfillment being protective variables. Data is provided to improve preventive measures for occupational health workers.(Luceño-Moreno, Talavera-Velasco, García-Albuerne, \& Martín-García, 2020)

This research is in line with Ayu Lestari's research (2020), entitled Analysis of Worker Stress Perceptions in the Covid-19 Pandemic Period, that there is an influence of the Independent Variable X3 (Workload).(Nawir, Maulana, \& Singkeruang, 2021) The tcount value is 0.7180 where the ttable value is 2.0211 , the ttable value $>$ tcount and the p-value in the sig column is $0.477>0.05$, meaning that the workload has no significant effect on the symptoms of service industry workers' stress. Independent Variable X4 (Working Conditions) The tcount value is 2.8450 where the ttable value is 2.0211 , the $\mathrm{t}$ table value < tcount and the p-value in the sig column is $0.007<0.05$, meaning that working conditions have a significant effect on the stress symptoms of service industry workers.

Based on the results of research, theory, and related research, the researchers assume that the workload and working conditions affect the symptoms of stress in health workers because excessive workloads cause stress and that can cause stress, coupled with pandemic conditions that can increase anxiety and stress. On the one hand, as health workers, they must continue to provide services to patients, on the other hand, the fear of being infected and being able to transmit it to their families is also a burden. In addition, comfortable and safe working conditions are also a factor that can cause stress, because when working conditions are safe and comfortable will make health workers can work well and not cause stress.

\section{CONCLUSION}

Based on the results and discussion, it can be concluded that: The company's regulation $(\mathrm{X} 1)$ has a significance value of $0.743>0.05$, which means that the company's regulation (X1) has no effect on stress symptoms (Y). Anxiety (X2) has a significance value of $0.461>0.05$, which means that worry $(\mathrm{X} 2)$ has no effect on symptoms of stress (Y). Workload (X3) a significance value of $0.007<0.05$, it means that there is an effect of workload (X3) on stress symptoms. Working conditions (X4), a significance value of $0.023<0.05$, it means that there is an effect of working conditions (X4) on symptoms of stress.

\section{REFERENCES}

Badrianto, Yuan, \& Ekhsan, Muhamad. (2020). Effect of work environment and job satisfaction on employee performance in pt. Nesinak industries. Journal of Business, Management, \& Accounting, 2(1).

Burdorf, Alex, Porru, Fabio, \& Rugulies, Reiner. (2020). The COVID-19

(Coronavirus) pandemic: consequences for occupational health.

Scandinavian Journal of Work, Environment \& Health, 46(3), 229-230.

Covid, C. D. C., Team, Vaccine Breakthrough Case Investigations, COVID, C. D.

C., Team, Vaccine Breakthrough Case Investigations, COVID, C. D. C.,

Team, Vaccine Breakthrough Case Investigations, Birhane, Meseret, 
Bressler, Sara, Chang, Gregory, \& Clark, Thomas. (2021). COVID-19 vaccine breakthrough infections reported to CDC - United States, January 1April 30, 2021. Morbidity and Mortality Weekly Report, 70(21), 792.

Cramer, Eleanor, \& Hunter, Billie. (2019). Relationships between working conditions and emotional wellbeing in midwives. Women and Birth, 32(6), 521-532.

d'Ettorre, Gabriele, Ceccarelli, Giancarlo, Santinelli, Letizia, Vassalini, Paolo, Innocenti, Giuseppe Pietro, Alessandri, Francesco, Koukopoulos, Alexia E., Russo, Alessandro, d'Ettorre, Gabriella, \& Tarsitani, Lorenzo. (2021). Posttraumatic stress symptoms in healthcare workers dealing with the COVID-19 pandemic: A systematic review. International Journal of Environmental Research and Public Health, 18(2), 601.

Elfering, Achim, Grebner, Simone, Ganster, Daniel C., Berset, Martial, Kottwitz, Maria U., \& Semmer, Norbert K. (2018). Cortisol on Sunday as indicator of recovery from work: Prediction by observer ratings of job demands and control. Work \& Stress, 32(2), 168-188.

Kumar, Manoj. (n.d.). Ashwani Kumar Sood.

Luceño-Moreno, Lourdes, Talavera-Velasco, Beatriz, García-Albuerne, Yolanda, \& Martín-García, Jesús. (2020). Symptoms of posttraumatic stress, anxiety, depression, levels of resilience and burnout in Spanish health personnel during the COVID-19 pandemic. International Journal of Environmental Research and Public Health, 17(15), 5514.

Meidina, Tri Retno Yova, Mudjihartini, Ninik, Gunarti, Dwirini Retno, Yulhasri, Yulhasri, Dewi, Syarifah, \& Hardiany, Novi Silvia. (2020). Analisis Komposisi dan Distribusi Batu Empedu di Laboratorium Fakultas Kedokteran Universitas Indonesia (FKUI) Jakarta. Jurnal Biotek Medisiana Indonesia, 9(1), 19-26.

Mélan, Claudine, \& Cascino, Nadine. (2022). Effects of a modified shift work organization and traffic load on air traffic controllers' sleep and alertness during work and non-work activities. Applied Ergonomics, 98, 103596.

Nawir, Fadliyani, Maulana, Syahrial, \& Singkeruang, A. (2021). Analysis of User Satisfaction with Fintech Applications: Fintek Syariah Use EUCS Method.

Ogińska-Bulik, Nina, Gurowiec, Piotr Jerzy, Michalska, Paulina, \& Kędra, Edyta. (2021). Prevalence and predictors of secondary traumatic stress symptoms in health care professionals working with trauma victims: A cross-sectional study. PloS One, 16(2), e0247596.

Søvold, Lene E., Naslund, John A., Kousoulis, Antonis A., Saxena, Shekhar, Qoronfleh, M. Walid, Grobler, Christoffel, \& Münter, Lars. (2021).

Prioritizing the mental health and well-being of healthcare workers: an urgent global public health priority. Frontiers in Public Health, 9.

Tresnaherdiarti, Anisa Farah. (2021). Hubungan Aktivitas Fisik dengan Quality of Life dan Performa Akademis Mahasiswa Kedokteran Tingkat 3 FKUI Tahun Akademik 2019/2020= Relationship Physical Activity between Quality of Life and Academic Performance of Medical Students University of Indonesia Level 3 Academic Year 2019/2020. 